論 文

$$
\text { 熱遮へいコーティングの界面はく離挙動に及ぼす熱時効処理の影響 }{ }^{\dagger}
$$

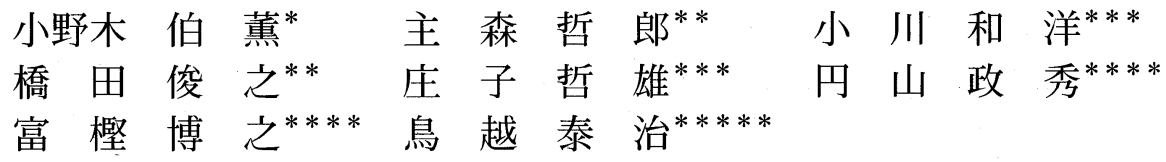

\title{
Influence of Thermal Aging on Interface Delamination of Thermal Barrier Coatings
}

\author{
by \\ Takamasa ONOKI ${ }^{*}$, Tetsuro TonomorI ${ }^{* *}$, Kazuhiro OGAWA ${ }^{* * *}$, Toshiyuki HashIDA ${ }^{* *}$, \\ Tetsuo ShoJI $^{* * *}$, Masahide MaruYama ${ }^{* * * *}$, Hiroyuki Togashi ${ }^{* * * *}$ and Taiji ToRIGoE ${ }^{* * * * *}$
}

Knowledge of the degradation mode in thermal barrier coatings (TBCs) is a prerequisite for the prediction of their remaining life of gas turbine blades. This paper describes the effects of thermal aging on the microstructure in a YSZ-based thermal barrier coating system deposited on Ni based superalloy substrates. The heat treatment of the TBC specimens were conducted at $1373 \mathrm{~K}$ for $100 \mathrm{~h}, 500 \mathrm{~h}$ and $1000 \mathrm{~h}$ in air for thermal aging. The thermally aged coating system had thermally grown oxide (TGO) layer between the substrate and the TBC. TGO consisted of not only alumina but also other oxides. This oxide layer that named mixed oxides (MO) is composed of $\mathrm{Ni}, \mathrm{Co}, \mathrm{Cr}$ and $\mathrm{O}$. Double cantilever beam (DCB) tests and 4 point bending tests were carried out in order to evaluate the TBC/substrate interface strength. The interface strength depended on the period of thermal aging in both type of tests. The interface strength increased initially up to the aging time of $100 \mathrm{~h}$, and then decreased drastically for the longer aging time. In DCB tests, crack propagated in the middle of YSZ layer for the thermally aged specimens, whereas delamination took place close to the YSZ-bondcoat interface in the unheated specimens. In 4 point bending tests, crack propagated along the interface between TBC and substrate. These results suggested that the interface strength depended on not only the formation of oxides but also the fracture properties of the top coatings.

Key words : Thermal barrier coating (TBC), Thermal aging, Thermally grown oxide (TGO), Double cantilever beam (DCB) test, 4point bending test, Interface strength

\section{1 緒言}

環境問題への適切な対処が世界的課題となっている現 在, 地球温暖化抑制のための $\mathrm{CO}_{2}$ 削減の観点から, 火力 発電システム, 特に発電用ガスタービンの作動ガス温度 をより上昇させることにより高効率化を図ることが求めら れている. 現在実用化が進められている $1500{ }^{\circ} \mathrm{C}$ 級発電用 ガスタービンは既に金属材料の耐熱限界を超えており，タ ービン翼等の高温機器部材を保護するための新しい材料 技術として熱遮へいコーティング (Thermal Barrier Coating : TBC) の適用が必要不可欠となっている. 1) 3) $\mathrm{TBC}$ のトップコートはイットリア安定化ジルコニアなど の遮熱特性に優れたセラミックス系材料が多用され，プ ラズマ溶射法などによってガスタービン翼にコーティン グが施されている.

TBC は高温酸化損傷，クリープ損傷，稼動停止による 熱応力などにより様々な損傷を受ける可能性がある。な
かでも TBC の脱落は, 金属基材が耐用温度を大きく超 える高温ガスに曝されることになるため，タービン翼に 深刻な損傷がもたらされる。皇のため, TBC の最終的な 脱落に至るまでのプロセス，すなわち TBC のはく離挙動 の把握は極めて重要である。とりわけ余寿命評価法確立 の観点からも損傷メカニズムについてはこれまでに様々 な研究がなされているが, (4) ガスタービン翼はその過酷な 使用環境のため，損傷を in situ でモニタリングすること は困難であり，未だ不明な点も多い．

$\mathrm{TBC}$ のはく離現象は，熱時効した $\mathrm{TBC} /$ 基材界面に酸 化皮膜が生成することや，気孔あるいは微小き裂の増加 による応力集中源の発生による機械的特性の低下等がそ の原因として考えられている. ${ }^{5)}$, 6) こで本研究では, 熱 時効の $\mathrm{TBC}$ のはく離挙動に及ぼす影響の基礎的検討を 行うことを目的に，熱時効处理を施した TBC 試験片を 用いて室温にて界面強度試験を行った。

\footnotetext{
$\dagger \quad$ 原稿受理 平成 14 年 5 月 16 日 Received May 16, 2002

* 東北大学大学院 日本学術振興会特別研究員 $=980-8579$ 仙台市青葉区荒巻字青葉, Graduate Student, JSPS Res. Fellow, Fracture Res. Inst., Tohoku Univ., Aoba-ku, Sendai, 980-8579

** 東北大学大学院工学研究科附属破壞制御システム研究施設 テ980-8579 仙台市青葉区荒巻字青葉, Fracture Res. Inst., Tohoku Univ., Aoba-ku, Sendai, 980-8579

*** 正会員 東北大学大学院工学研究科附属破壞制御システム研究施設 ̄ $980-8579$ 仙台市青葉区荒巻字青葉, Fracture Res. Inst., Tohoku Univ., Aoba-ku, Sendai, 980-8579

東北電力(株)＝９80-0014＼cjkstart仙台市青葉区本町，Tohoku Electric Power Co., Inc., Aoba-ku, Sendai, 980-0014

三菱重工業㑣)高砂研究所 †676-8686 高砂市荒井町新浜, Mitsubishi Heavy Industries, Ltd., Arai-cho, Takasago, 676-8686
} 


\section{2 実 験 方 法}

\section{$2 \cdot 1$ 供試材および試験片}

供試材は $\mathrm{Ni}$ 基超合金基材 (Tomilloy：90×90×5 $\left.\mathrm{mm}^{3}\right)$ 平板上にボンドコート (CoNiCrAlY) を減圧プラズ マ溶射 (LPPS), ならびにトップコート (8mass $\% \mathrm{Y}_{2} \mathrm{O}_{3}$ 安 定化 $\mathrm{ZrO}_{2}$ ：YSZ）を大気圧プラズマ溶射 (APS) した. キャリアガス圧力など溶射条件を Table I に整理する. ボンドコートの膜厚は $90 \sim 110 \mu \mathrm{m}$, 平均值 $100 \mu \mathrm{m}$ であ つた. トップコートは $300 \sim 360 \mu \mathrm{m}$ の範囲であり, 平均 值は $330 \mu \mathrm{m}$ であった. 熱時効処理は電気炉を用い大気中 $1373 \mathrm{~K}$ にて行った．時効時間はそれぞれ $0 \mathrm{~h}, 100 \mathrm{~h}, 500 \mathrm{~h}$ ， $1000 \mathrm{~h}$ とし, 所定の時間経過後, 電気炉から取り出し, 室温まで自然冷却させた。その後界面強度試験に供する ために所定の大きさに切り出し，試験片を作製した.

\section{$2 \cdot 2$ 界面強度試験}

セラッミクスコーティング層と基材との界面はく離強 度を測定する方法として, 引張試験と曲げ試験が代表的 なものとして挙げられる. TBCのはく離挙動の検討を行 うために, 引張についてはダブルカンチレバービーム (Double Cantilever Beam : DCB) 試験 ${ }^{7)}$ を室温中にて行 った. Fig. 1 にDCB 試験片の概略図を示す.トップコー トおよびボンドコートをダイヤモンドやすりを用いて片側 のみ端面から初期き裂長さ分を削り落とし，基材と同寸 法・同材質の梁をエポキシ系接着剤 (CHIBA-GEIGY 社 製 Araldite）を用いて TBC 上に貼付した。接着剂硬化 後，余分な接着剤を除去して試験に供した。 なお，用い た接着剤は，TBCの気孔を介して広範に浸透することは なく，き裂進展経路に影響を及ぼしていないことを実験 後の観察により確認している. 引張時においてはユニバ ーサルジョイントを用いることで, 試験片にかかるねじ り等の効果を低減した。 DCB 試験はコンプライアンス法 による荷重負荷および除荷の繰り返しによってき裂を進 展させ, 荷重 $P$ と開口変位 $\delta$ を計測し, $P-\delta$ 曲線から式 （1）を用いて，き裂長さ $a$ を算出した.

$$
\delta=\frac{4 P}{E^{\prime} t}\left(\frac{a}{h}+0.64\right)^{3}
$$

式 (1)中の $h(5 \mathrm{~mm}), t(10 \mathrm{~mm})$ は Fig. 1 に同時に示し たようにそれぞれ試験片の基材の厚さおよび幅を示す. 試験片の長手方向の長さは $100 \mathrm{~mm}$ である。なお，開口

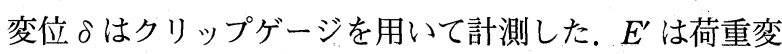
位曲線からコンプライアンス法によって求めたみかけの 有効縦弾性係数の值である. 開口変位速度は $0.002 \mathrm{~mm} / \mathrm{s}$ であった. DCB 試験において得られたき裂長さ $a$ と $P-\delta$ 曲線からエネルギー解放率 $G$ を算出し, その值で界面は く離強度を評価した。

曲げについては 4 点曲げ試験を室温にて行った. Fig. 2

Table I. Conditions of plasma spraying.

\begin{tabular}{|c|c|c|c|c|c|c|c|}
\hline & $\begin{array}{c}\text { Doposition } \\
\text { Mothod }\end{array}$ & Material & $\begin{array}{c}\text { Curront } \\
(\mathrm{A})\end{array}$ & $\begin{array}{c}\text { Stand off } \\
\text { Distanco } \\
(\mathrm{mm})\end{array}$ & $\begin{array}{c}\text { Gas Pressure: } \\
\text { Ar (MPa) }\end{array}$ & $\begin{array}{c}\text { Gas Pressure: } \\
\text { Ho (MPa) }\end{array}$ & $\begin{array}{c}\text { Carrier Gas } \\
\text { Pressuro: Ar } \\
(M P a)\end{array}$ \\
\hline $\begin{array}{c}\text { Bond } \\
\text { Costins }\end{array}$ & LPPS & CoNiCrAN & 800 & 140 & 0.34 & 0.34 & 0.14 \\
\hline $\begin{array}{c}\text { Top } \\
\text { Coating }\end{array}$ & APS & BmassKYS & 900 & 140 & 0.34 & 0.34 & 0.14 \\
\hline
\end{tabular}

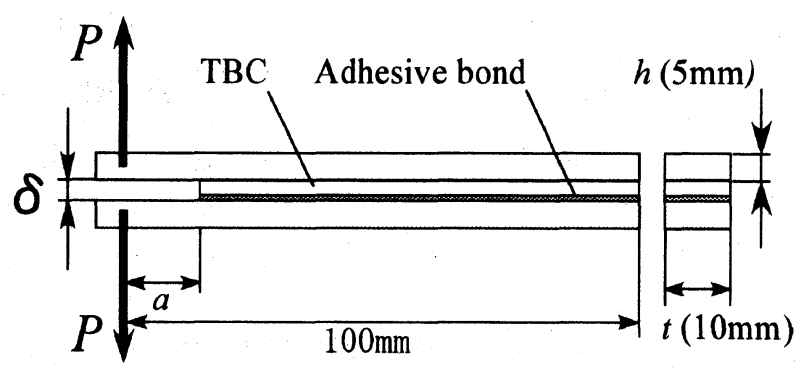

Fig. 1. Schematic illustration of DCB test specimen.

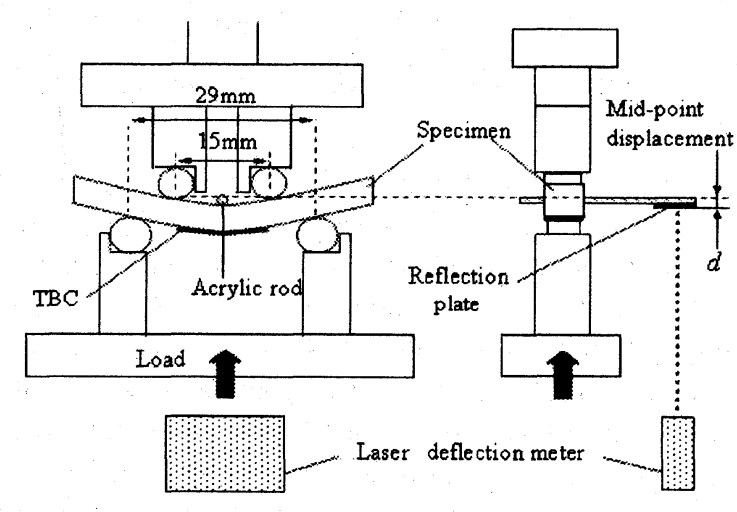

Fig. 2. Schematic illustration of 4 point bending test.

に概略図を示す. 4 点曲げ試験片は，トップコートなら びにボンドコートを上部支点間距離 $L(15 \mathrm{~mm})$ だけ残る ようにダイヤモンドやすりで両端から削り落とした試験 片を用意し，曲げ試験に供した．TBC と基材との界面間 に発生するひずみ $\varepsilon$ は, 式 (2) により求めた.レーザー 変位計により測定した試験片中央部の変位 $d$ から試験片 の上部支点間距離 $L$ における局率半径を算出し，この值 を基に簡単な幾何的関係から導かれるものである.

$$
\varepsilon=\frac{d t}{d^{2}+(L / 2)^{2}+d t}
$$

基材の厚み $t$ および試験片幅はそれぞれ $5 \mathrm{~mm}$ である。 ロスヘッド速度は $0.002 \mathrm{~mm} / \mathrm{s}$ とした。試験片中央部は 変位計測のために先端に反射板を固定したアクリル棒を ゴムバンドによって設置してある．試験中上部支点間内 において試験片長手方向と垂直に TBC 中に発生するき 裂と長手方向と平行に TBC と基材との界面に発生する はく離長さを目視によって詳細に観察した。

いずれの試験法もロードセル, 変位計等からの出力信 号はアンプなどを介してすべてパーソナルコンピュータ へ取り込んだ。

\section{$2 \cdot 3$ 光学・走査型電子顕微鏡による観察}

熱時効のみ, およびはく離試験後のそれぞれの試験片に ついて, 光学顕微鏡ないし走查型電子顕微鏡 (HITACHI 社製 FE-SEM S-4300）を用いて，断面ならびにはく離面の 観察を行った.さらにエネルギー分散 X 線分光器 (EDX) によりはく離界面近傍の元素を分析した。熱時効前後の 試験片について，トップコートとボンドコートとの界面 を観察するため，それぞれ断面をダイヤモンドペースト でバフ研磨した後, カーボン蒸着させた。観察は走查型 
電子顕微鏡 $(\mathrm{SEM})$ 莆用いて行い，钼察と同時にEDX による元素分析も行った。

\section{3 実験結果・考察}

\section{3・1 熱時効材の断面 SEM 観察}

SEM 観察の例として 0 h と $1000 \mathrm{~h}$ 熱時效材の断面像を Fig. 3 に示す。下側から基材，ボンドコート，トップコ 一トの順である。トップコートは大気圧溶射により作製 されているため，図中トップコート内ではき裂や気孔が 形成されていることがわかる。未時効材においても気孔

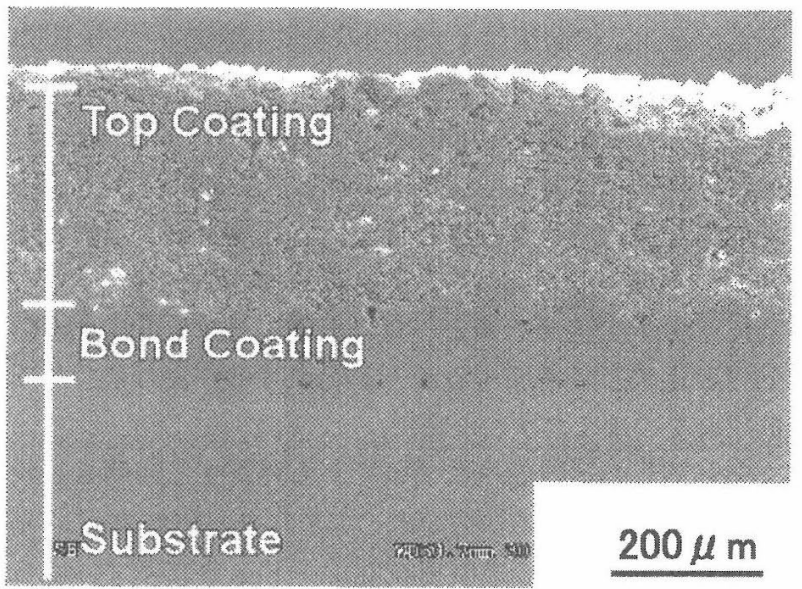

(a) $\mathrm{Oh}$

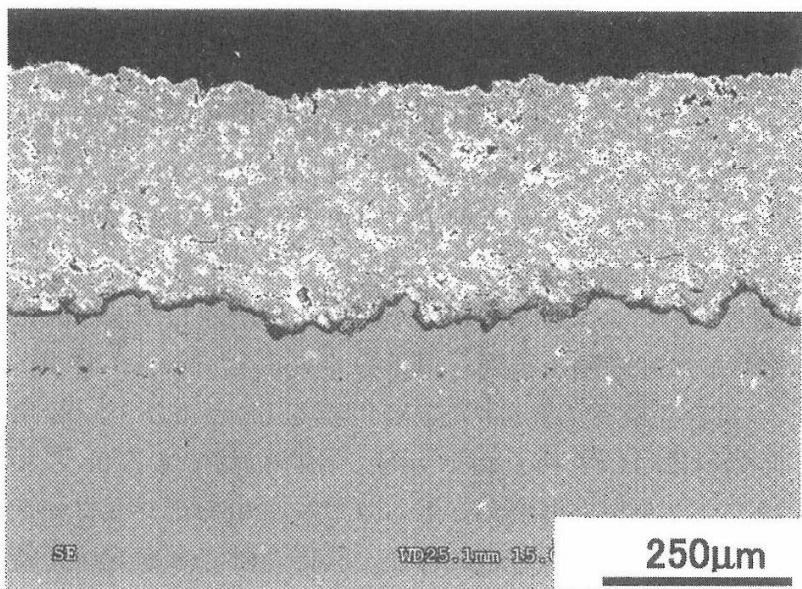

(b) $1000 \mathrm{~h}$

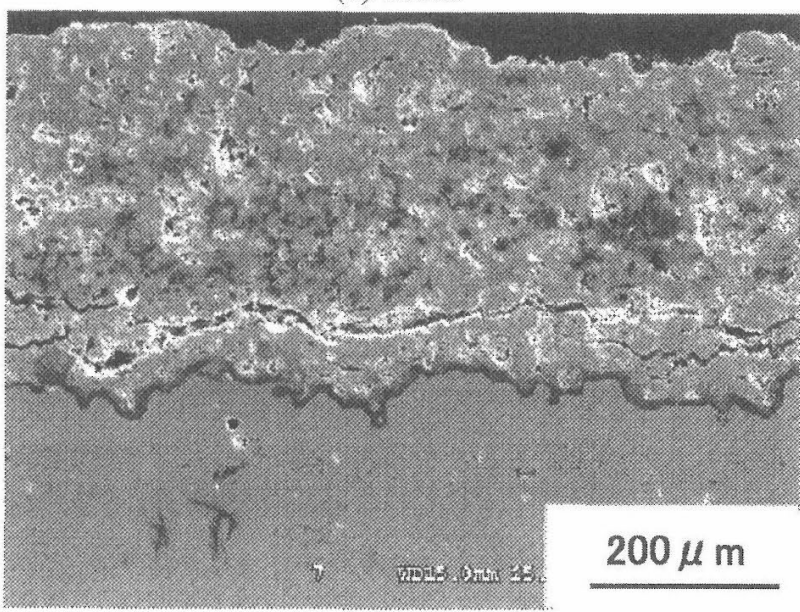

(c) $1000 \mathrm{~h}$

Fig. 3. Typical SEM images of cross section of TBC.
が存在するが，熱時効が進むにつれ，気孔やき裂などの 損傷が增大していることが各種熱時効材の断面の SEM 䚁察によりわかった。Fig. 3 (c) に例示したように比較 的大きなき裂や気孔が観察される場所もあった。これは TBC と基材の熱膨張係数の差による熱応力等が複合的に 作用して形成されたものと考えられる。

熱時効材においては，ボンドコートとトップコートと の界面に厚さ数 $\mu \mathrm{m}$ の反応層が生成していた。これは熱 成長酸化物 (TGO) であり，その主な組成は従来知られ ているアルミナ $\left(\alpha-\mathrm{Al}_{2} \mathrm{O}_{3}\right)$ であった. ${ }^{8}$ しかし, Fig. 4 に 示した EDX面分析から, 本研究に扔いて解析した試験 片について，その組成は均質なものではなく，部分的に アルミナ以外の物質も存在していることが判明した。他 の研究者に抢いては，その組成が Spinel や Yttrium alu-

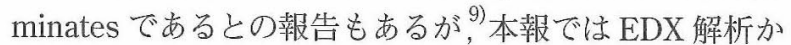
ら Cr をはじめとする複数の元素が同定されたため，多 くの酸化物が混合した酸化物層も形成しているものと考 气られる。

以降ではこの酸化物層を混合酸化物層 (Mixed Oxide ：MO) と呼ぶことにする，MO 層は熱時効により生成 したアルミナとトップコートとの界面に局所的に形成さ れていた，MO層は微細な多孔質構造をとっているのに 対し，アルミナ層には顕著な気孔は見られなかった。時 効時間の増大に伴い, Fig. 4 (a) に見られるようにTGO 中に気孔が形成されていた。 SEM 観察の結果から, 熱時 効時間に伴う TGO 層の厚さを測定し, 得られた結果を Fig. 5 に示す。図中の值は 100 カ所の平均值である。こ こで黒四角で示してあるTGO 厚さは，アルミナ層（白

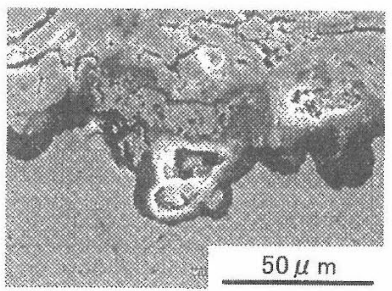

(a) SEM

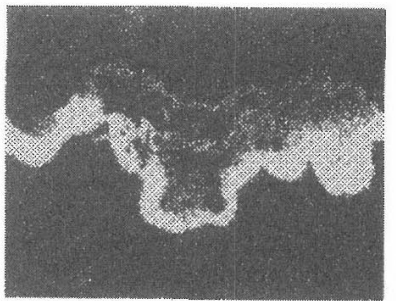

(b) $\mathrm{Al}$

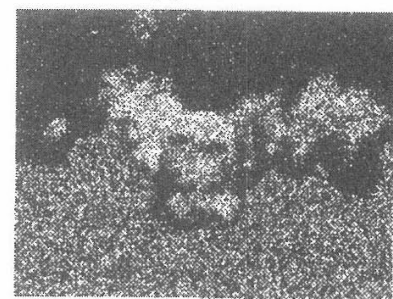

(d) $\mathrm{Co}$

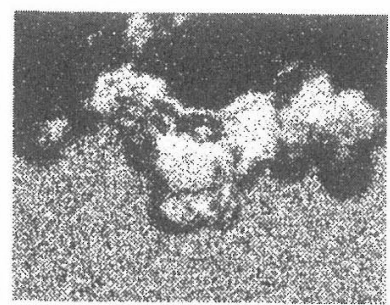

(c) $\mathrm{Cr}$

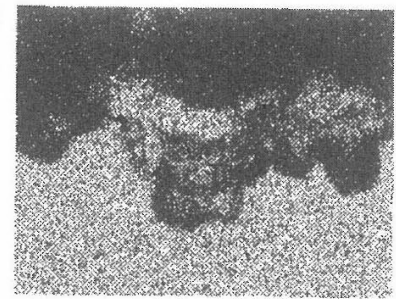

(c) $\mathrm{Ni}$
Fig. 4. EDX analysis results of $1000 \mathrm{~h}$ aged specimen. 


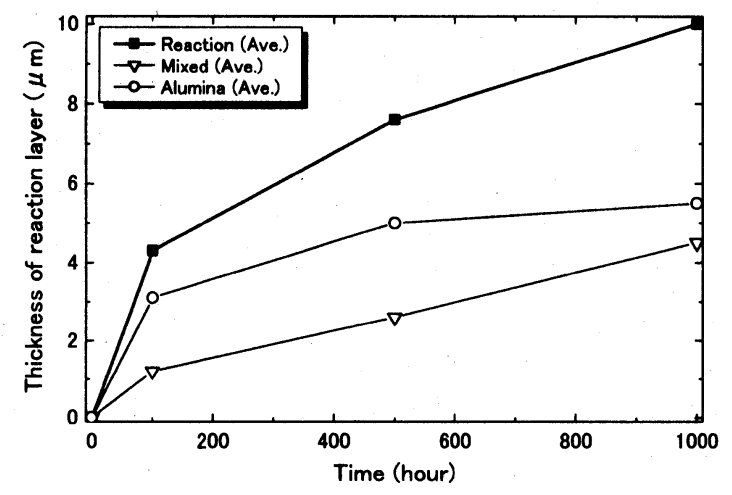

Fig. 5. Relationship between the aging time and the thickness of each layer.

丸）と MO 層（白三角）の和である．さらに熱時効によ るトップコート断面の硬さ変化をビッカース硬度計（フ イッシャー・インストルメント社製）で計測した結果を Fig. 6 に示す.これらの計測結果は 20 ヶ所における計 測結果の平均値である。試験荷重は $0.98 \mathrm{~N}$ である。未時 効材と比較して, 100h 熱時効材の硬度は増大している. これはプラズマ溶射されたトップコートが未焼結粒子を 含むため，熱時効により焼結と推察される現象の進行に よりもたらされたものと判断される. ${ }^{10)}$

一方, $500 \mathrm{~h}$ 以上の時効材では硬度が低下する傾向が見 られた. TBC 断面に見られる気孔・き裂面積の相対比率 を Fig. 7 に示している.トップコートである YSZ と MO 層

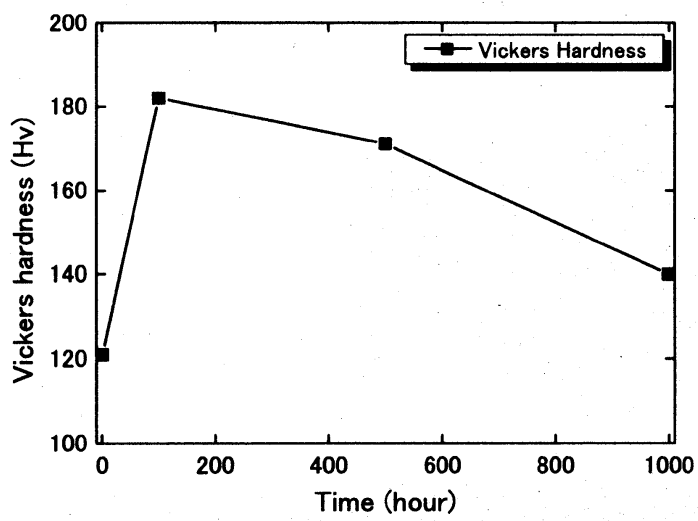

Fig. 6. Aging time dependence of Vickers hardness.

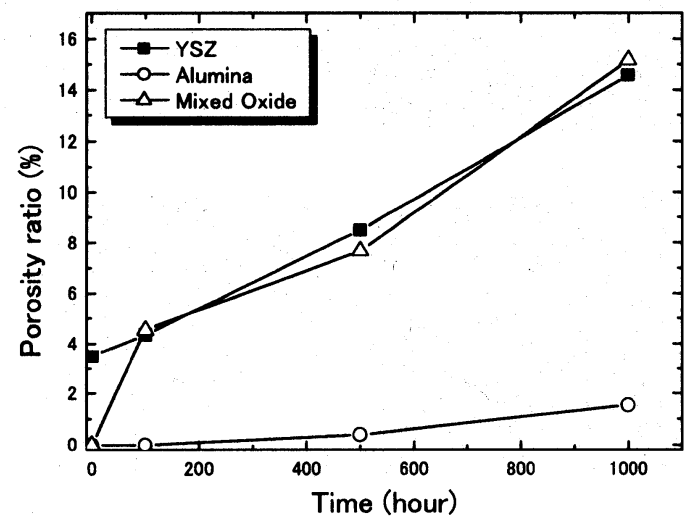

Fig. 7. Time dependence of porosity ratio.
中においては熱時効に伴って気孔・き裂が増加している ことがわかる.よってトップコートの硬度は熱時効の初期 段階では焼結によるものと推察される現象により一時的 に増加するが, 長時間の熱時效段階では気孔・き裂の増大 の影響が支配的となり硬度が減少したものと考えられる。

\section{$3 \cdot 2$ DCB 試験}

DCB 試験における $P-\delta$ 曲線を Fig. 8 に示す。な打試 験片の幅 $t$ で荷重 $P$ を除することにより, 単位幅あたり の荷重として評価を行った。 図中矢印はその時点で試験 片が急速に破断したことを表している. 曲線により囲ま れる面積は熱時効をうけることにより一旦増加すること がわかる。この面積は，4 種類の時効試験片のうち $100 \mathrm{~h}$ 時効材が最大であり, 時効が進むにつれて面積は漸減し

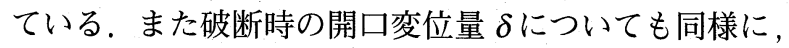
熱時効初期では最大変位量が増加し，4 種類のうち $100 \mathrm{~h}$ 時効材が最大で, さらなる時効により減少する傾向を示 した. 熱時効に伴う $P-\delta$ 曲線に打ける変化挙動から, $\mathrm{TBC}$ は熱時効をうけると一旦は引張に対する抵抗が未時 効材と比較して増加するが, その後時効が進むにつれて 低下していくことがわかった.

それぞれの熱時効材について，き裂長さと初期き裂長 さの差であるき裂進展量 $\Delta a$ とエネルギー解放率 $G$ に基 ういて整理したき裂進展抵抗曲線を Fig. 9 に示す。さら にき裂進展抵抗を所定のき裂位置で, 熱時効時間に対し て整理したものを Fig. 10 に示す。熱時効材については, 熱時効を受けることによりトップコートのき裂進展抵抗 は一旦上昇し, その後時効時間の増大に伴い低下するこ とがわかる.すすおわち熱時効の初期段階ではトップコー 卜層の焼結と思われる現象によりその破壊特性が向上す るが ${ }^{10)}$ その後強度は低下していくことがわかる。この破 壊力学的パラメータに基づく結果は，上述した組織観察 ならびに硬度測定結果と調和的である。

DCB 試験後の断面の SEM 写真を $0 \mathrm{~h}$ および $1000 \mathrm{~h}$ 熱 時効材について Fig. 11 に示す。未時効材である $0 \mathrm{~h} に お ~$ いては，き裂進展経路がトップコート中のボンドコート との界面近傍であるのに対し, 熱時效材である $1000 \mathrm{~h}$ 時 効材はき裂がトップコートのほぼ中央部を進展している ことがわかる. また時効時間によらず，すべての熱時効 材においてトップコート中央部をき裂が進展しているこ とが観察された。つまり DCB 試験においては熱時効材 と末時効材とではき裂進展経路が異なることがわかった。 本研究で実施したトップコートの硬度測定結果に基づけ ば，熱時効初期に扔いては硬度が増大して打り，このこ とは界面近傍の破壞特性も少なくとも一時的に向上する ことが考えられる.また高らの研究によれば, ${ }^{11)} \mathrm{TGO}$ で あるアルミ゙厚さが約 $2 \mu \mathrm{m}$ までは界面破壊勒性が TGO 厚さと共に増加することを報告している。これは硬度測 定の結果と調和的であり, 両者の結果は共に熱時効の初 期には界面の破壊特性が改善されることを示唆している. 従って $100 \mathrm{~h}$ 時効材では界面の破壊特性が向上し, き裂 が界面ではなくトップコート中をき裂が進展したものと 考えられる. $100 \mathrm{~h}$ 以上の時効材については, 熱時効によ 


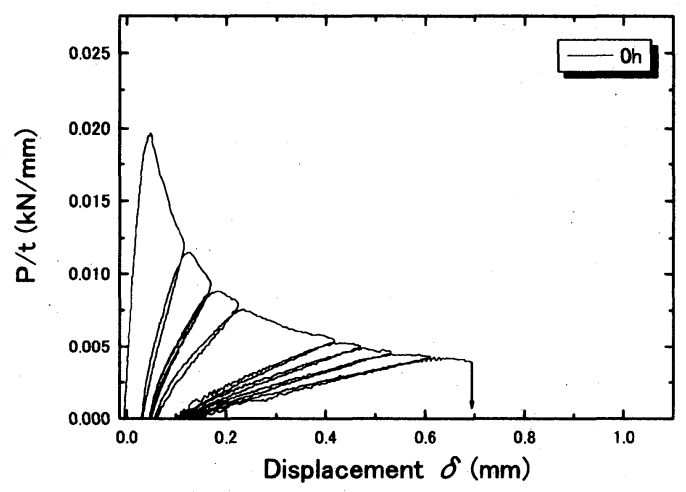

(a) $0 \mathrm{~h}$

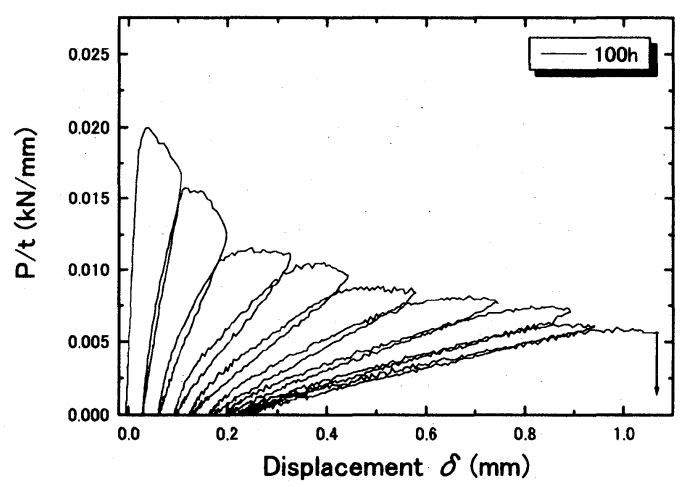

(b) $100 \mathrm{~h}$

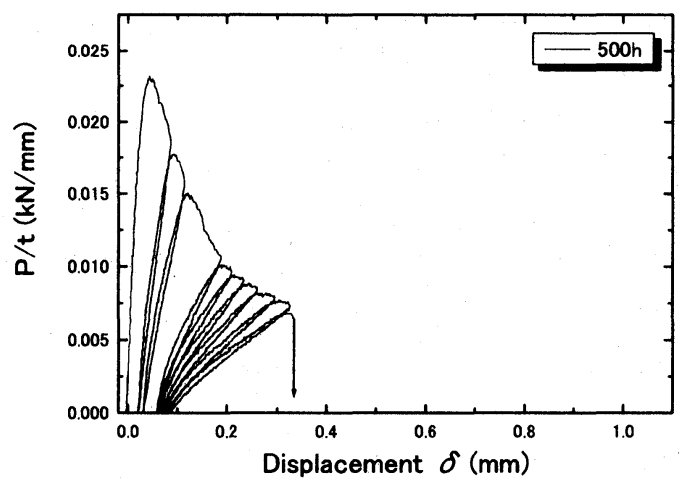

(c) $500 \mathrm{~h}$

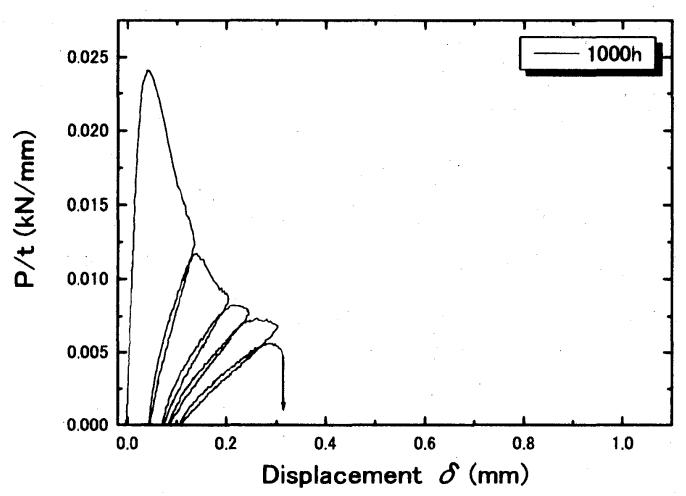

(d) $1000 \mathrm{~h}$

Fig. 8. Displacement-Load curve of DCB test.

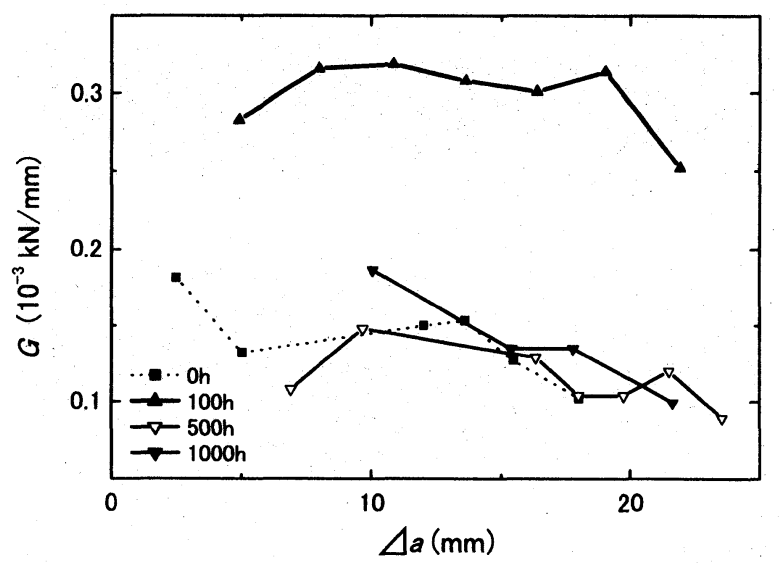

Fig. 9. G-based resistance curve.

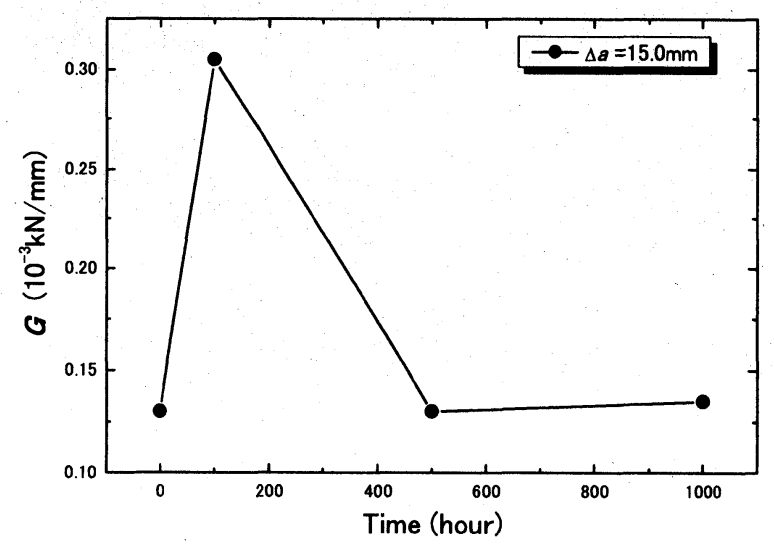

Fig. 10. Time dependence of energy release rate.

りトップコート内に形成された気孔・き裂の影響を反映 して界面強度低下が予想されるものの，界面に対して垂 直方向への引張に対する破壊特性に関しては，界面の劣 化よりもトップコートの劣化の方が支配的となり，結果 としてトップコート中をき裂が進展したものと推察され る.すなわち DCB 試験においてはき裂端周辺の高い引 張応力場の領域が比較的広く，熱時効によって強度的に 脆弱になった部位がき裂の発生箇所になるものと考えら れる。

TBC はガスタービンの種々の構成要素に適用され，発 生する応力状態は構成要素毎に異なる。また運転条件に も依存する，従って TBCの信頼性確保のためには種々 の応力状態における破壊挙動に関する知見の蓄積が要求 される。 DCB 試験で観察されたトップコート層内のき裂 進展挙動は, トップコートに打ける破壊特性の経年劣化 に対する検討も重要であることを示唆している，TBC 中 のき裂発生位置は材料的な劣化のみならず, 残留応力の 分布にも依存することが考えられる．本研究で観察され た熱時効材におけるトップコート中央部でのき裂進展の 定量的な解明については, 残留応力の影響も含めて今後 詳細に検討することが必要である。

\section{$3 \cdot 34$ 点曲げ試験}

4 点曲げ試験中 TBC が完全にはく離するまでの様子を 目視によって詳細に観察した。試験片両側面を目視によ 


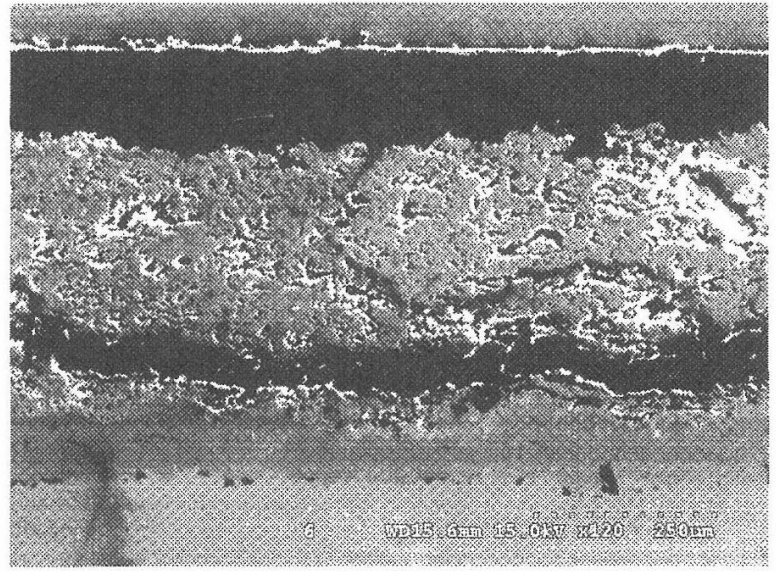

(a) $\mathrm{Oh}$

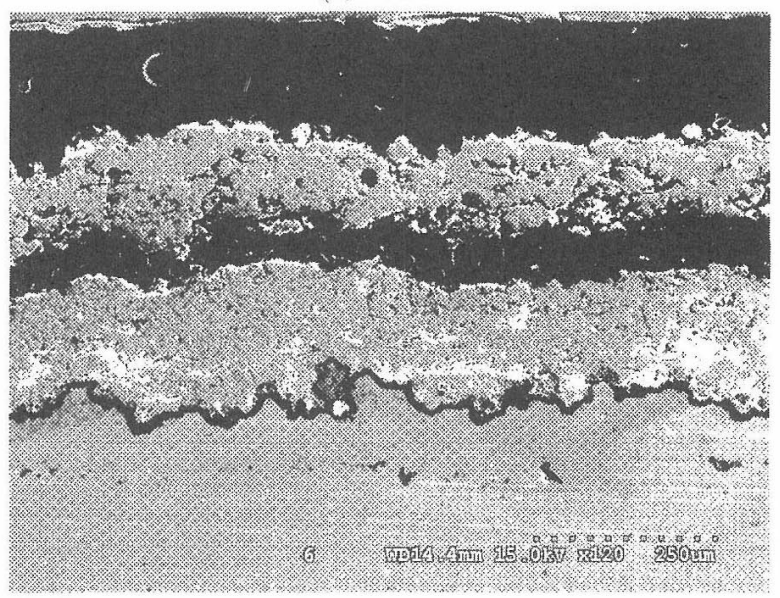

(b) $1000 \mathrm{~h}$

Fig. 11. Photographs of the specimens after DCB test.

り評価した TBCの平均的はく離長さ $l$ と試験前の TBC の全長 $L$ より TBCのはく離率 $l / L$ を求め, 曲げによる ひずぬとの関係をFig. 12 に示している。旮れでれの時 効材について，はく離が50\% 進行した時点のひずみ $\varepsilon_{50 \%}$ をFig. 12 の結果より求め， $\varepsilon_{50 \%}$ と知時効時間との関係 をFig. 13 に示している。これより TBC はく離強度をひ ずみ $\varepsilon_{50 \%}$ で評価すると，100h 時效材は無時効材と比較し て一日上昇するが，その後はく離強度は低下していくこ とがわかった。4点幽げ試験における詳細な観察ならび

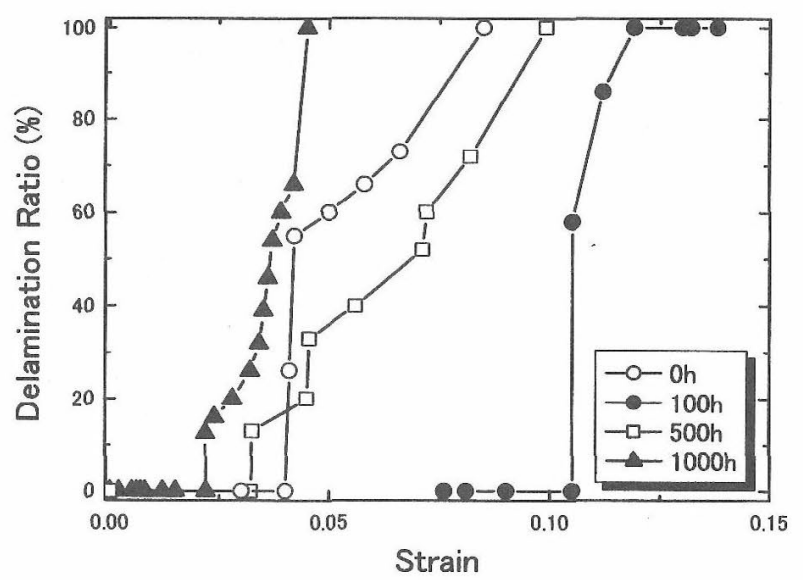

Fig. 12. Relationship between delamination ratio and strain.

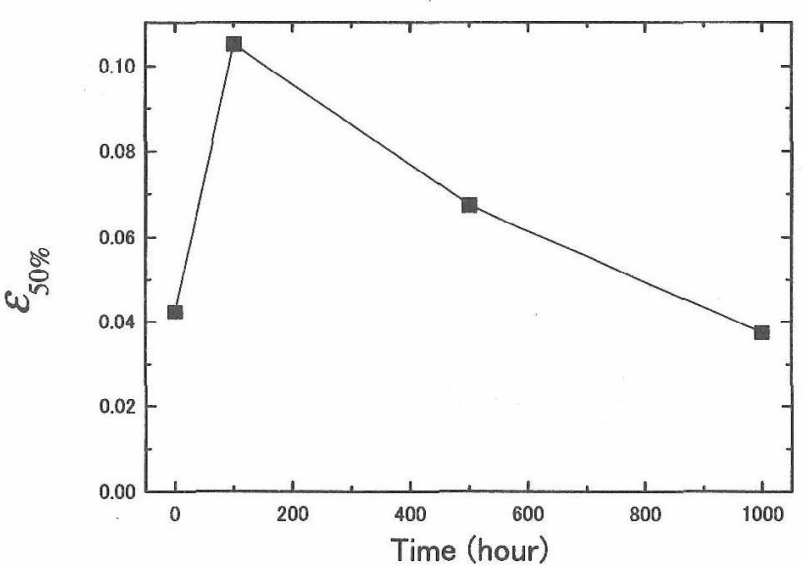

Fig. 13. Aging time dependence of delamination ratio.

にSEM 観察から，TBCのはく離・脱落は熱時効時間に よらず全ての試験片で巨視的にはトップコートノボンド コート界面の近傍で発生することがわかった。しかしな がら，熱時効時間によって破壞過程の詳細は異なってい る。TBCの曲げ負荷に伴うはく離挙動は, 通常のセラミ ックス溶射材と同様に, 曲げによりトップコートがコー ティング面方向の引張を受け，トップコートを分割する ようにマルチプルクラックが発生する。党文の後マルチプ ルクラックがトップコートを貫通し, TBC 界面近傍で屈 曲することによりコーティング界面を進展するはく離き 裂となって最終的に TBCの脱落に至る。未時効材, 100h 時効材, 1000h 時效材はそれぞれトップコートにマ ルチプルクラックが発生し, これがトップコートノボン ドコート界面近傍に拁いて屈曲することにより，はく離 が発生して脱落に至った。特に熱時効材についてはTGO 層にはく離き裂が発生していた。Fig. 14 に試験中断材 の写真を示军。トップコート表面ははく離挙動観察のた めにインクで黑く着色してある.マルチプルクシックに よって分割された TBC が一部はく離していることが観察 される。

500h 時効材だけは曲げの初期段階から TGO 層扎よび その近傍にはく離き裂が発生し，トップコートにマルチ プルクラックが生じることなく $\mathrm{TBC}$ 全体がはく離した。 Fig. 15 に完全にはく離する前に試験を中断した $500 \mathrm{~h}$ 時 效材の写真索示す。机はTBCのトップコート面方向 の引張に対する強度が比較的大きく，マルチプルクラッ ク発生以前にTGO 生成などによる界面の劣化によって, 先に TBC 界面にはく離き裂が牛成し TBC 脱落に至った ものと考えられる。コーティング界面の劣化を TGO 生 成量だけで評価するならば $1000 \mathrm{~h}$ 時效材についても $500 \mathrm{~h}$ 時効材と同様の挙動を示すものと考光られるが, $1000 \mathrm{~h}$

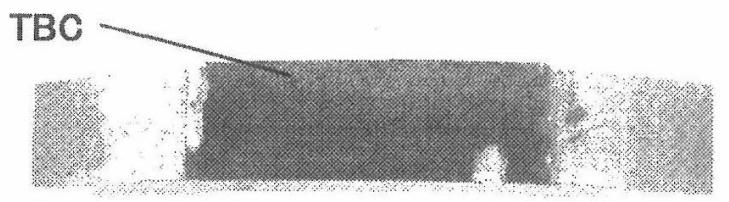

Fig. 14. Photo of 4 point bending specimen of $100 \mathrm{~h}$ aging. 


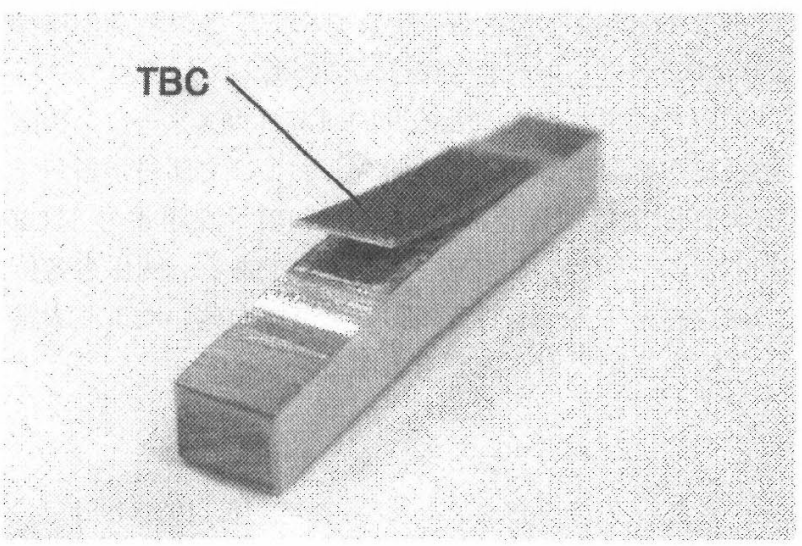

Fig. 15. Photo of 4 point bending specimen of $500 \mathrm{~h}$ aging.

時効材ではトップコートの劣化がさらに進みトップコー トへのマルチプルクラック生成が先に発生して，その後 界面はく離に至ったものと考えられる。

4 点曲げ試験後, はく離したコーティングのはく離面 について光学顕微鏡による観察を行った。未洔効材， 1000h 時効材のものを Fig. 16 に示す。下段が低倍率， 上段が高倍率における写真である。未時効材の TBC は く離面はほとんどトップコートである YSZであり，僅か に点在する黒い部分はボンドコートである CoNiCrAlY で あると考党られる。一方，1000h 時効材のはく離面には， 多量の青色の物質が存在していた。高倍率钼察から，こ れらは青色の部分と黒色の 2 種類あることがわかった。 このはく離面をSEM/EDX よる面分析を行った結果 $\mathrm{Al}$, $\mathrm{Cr}, \mathrm{Co}, \mathrm{Ni}, \mathrm{O}$ の存在が示されたことから, 熱時効材の はく離面に存在するこれらの物質はTGOであることが わかった。このはく離面に存在する物質は熱時効時間と 伴に増加していることから，TGO が TBC はく離き裂進 展の優先的なサイトとなっていると考えられる。曲げ武 験においては，DCB 試験片とは異なりコーティング面に 垂直方向に発生する応力が小さく，面内応力が主たるも のであるために熱時効材においてもトップコート内でき 裂進展せず界面近傍ではく離が発生したものと考えられ る. TGO 厚さすなわち TGO 生成量は熱時効に伴って増 加して扣り，Fig. 13 に示したTBCはく離強度と比較す ると TGO 生成量と TBC はく離強度との間には強い相関 があると思われる。 Rabiei らの研究によれば,TGO 厚さ が一定值を超えた段階でTGO /ボンドコート界面近傍 での極端な密着強度の低下が発生することを報告してい る。本研究においても同様の傾向が認少られる。つまり $100 \mathrm{~h}$ 時效材の TGO 厚さと $500 \mathrm{~h}$ 時效材の TGO 厚さとの 間にしきい值が存在しているものと思われる. Rabiei ら の研究によれば その值は5.5〜 $6 \mu \mathrm{m}$ であると報告して いる。また高らの研究によれば ${ }^{11)} 8$ - $10 \mu \mathrm{m}$ と報告して いる。Fig，5から本研究においてもこれらに近い值であ ることがわかる。しかしながら 4 点曲げ試験に打いて， 前述したように熱時効時間に依存して異なるマルチプル クラック挙動ならびにTBC はく離挙動を示したことは， $\mathrm{TGO}$ 生成量の夕によって TBCのはく離強度を定量的に

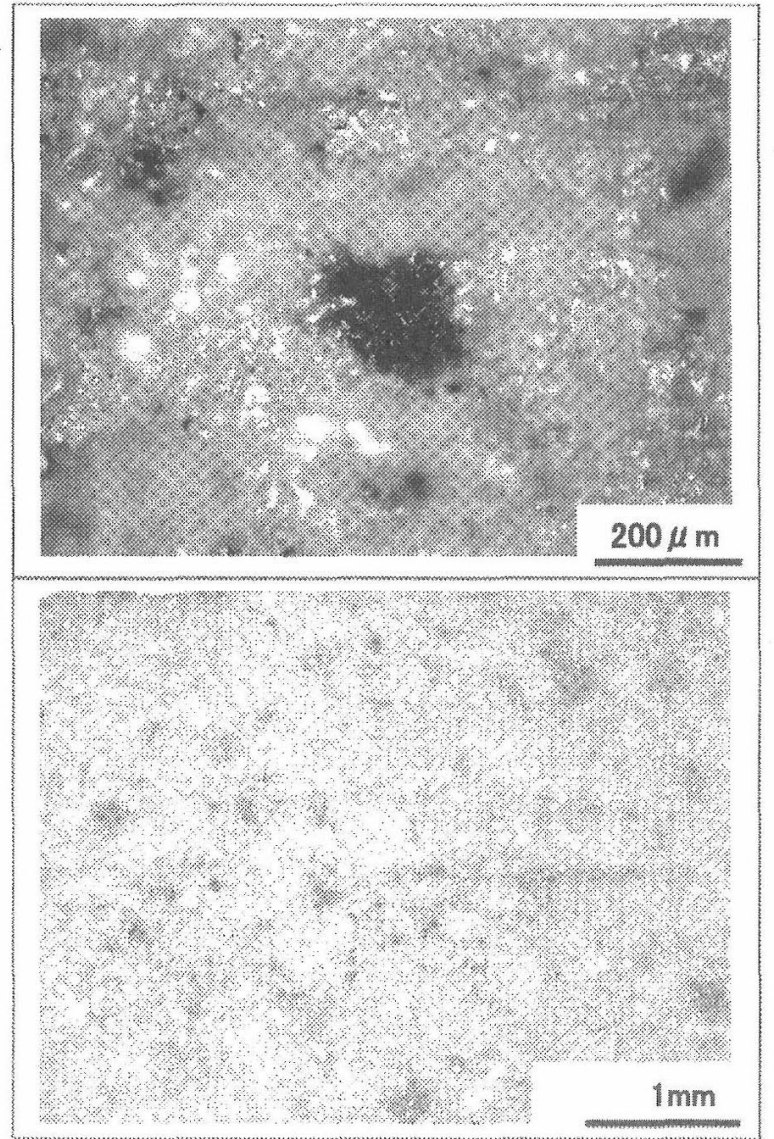

a) $0 \mathrm{~h}$

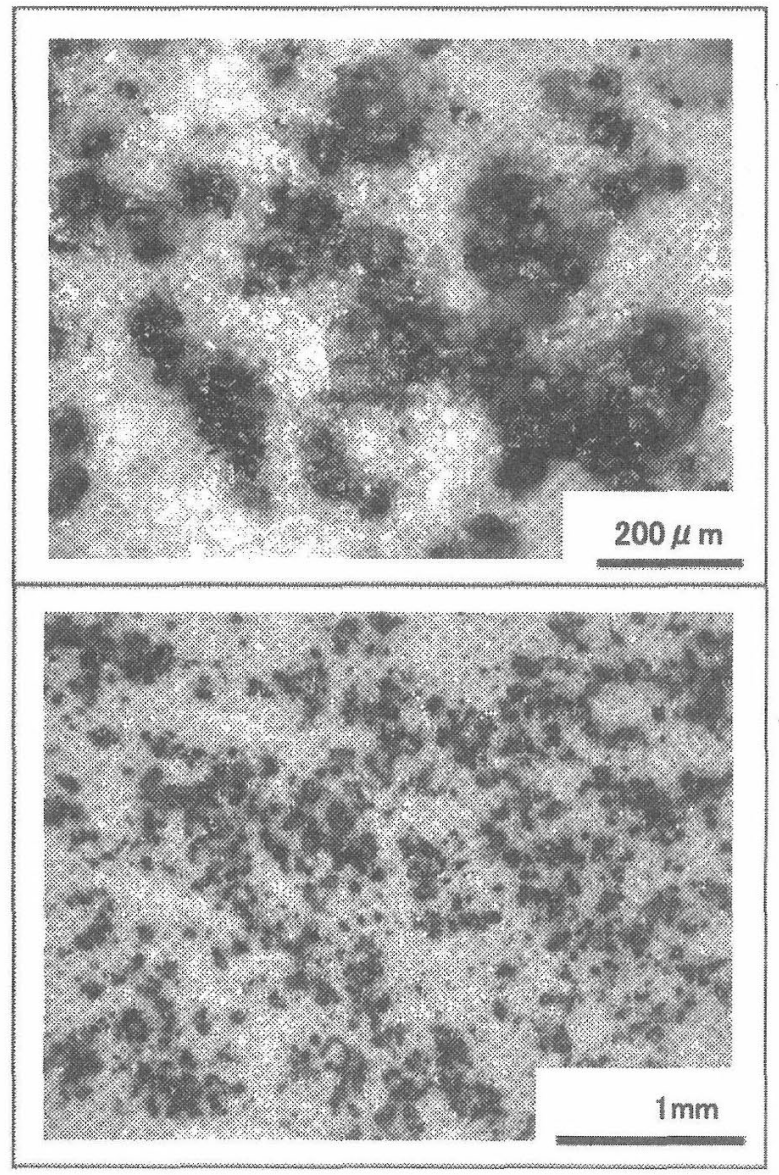

b) $1000 \mathrm{~h}$

Fig. 16. Photographs of delaminated top coat layer. 
評価できないことを示唆している。曲げ試験に打ける $\mathrm{TBC}$ のはく離強度は TGO 生成などの界面自体の劣化だ けでなく，気孔・き裂等の形成によるトップコートの劣 化が複合的に TBC はく離強度に影響を及ぼしているも のと考える必要があろう。

\section{4 結言}

本報では，発電用ガスタービン翼材料に用いられる熱 遮へいコーティング (TBC) のはく離挙動に対する熱時 効の影響について調查・検討を行った，その結果，以下 の結論を得た。

(1) 熱時効によりトップコート／ボンドコート界面に 生成する TGO は, アルミナだけではなく, 多くの酸化 物が存在し, 混合酸化物 (MO) 層も確認された.さらに MO 層中には気孔が多数形成されていることも確認され た. TBCのはく離はアルミナの生成量だけでなく, MO の存在も，はく離挙動の変化に関与している.

(2) 引張試験である DCB 試験においては，未時効材 はトップコート中のボンドコート界面近傍にはく離が進 展し，熱時効材はトップコート中央部がはく離き裂進展 の経路であった．時効材のき裂進展の経路がトップコー トあることから, 熱時効によるトップコート自体の劣化 が界面の劣化よりも支配的であることが示唆される．時 効に伴って, TBC はく離強度は未時効材と比較して一時 的に上昇するが，次第に低下する.

(3) 4 点曲げ試験においても, 熱時効に伴い TBC は く離強度は未時効材と比較して一時的に上昇するが次第 に低下する。曲げによる TBC はく離はトップコート中に マルチプルクラックが発生し，それらがコーティング界 面を進展することで誘起される。曲げ試験においては， 熱時効により界面近傍に生成する TGO がはく離き裂進 展の優先サイトとなる，熱時効による TBC はく離強度
低下は TGO 層の厚さだけでなく, トップコートの機械 的特性の変化と合わせて複合的に影響している。

本研究は東北電力(株)との共同研究「ガスタービン用耐 熱材料の寿命予測に関する研究」および文部科学省科学 研究補助金特別推進研究 (COE) (2) (課題番号 $11 \mathrm{CE}$ 2003）の一環として実施されたものである。関係者各位 に謝意を表する。本研究の実験に御協力戴いた東北大学 大学院生吉田晃君に謝意を表する.

\section{参 考 文 献}

1）霜鳥一三，鈴木隆夫，セラミックス，16，163 (1981).

2 ）大木基史, 武藤睦治, 大原 稔, 高橋雅士, 石橋達弥, 溶接学会論文集, 16, 395（1998）.

3 ) G. W. Goward, Materials Science and Technology, 2, 194 (1986).

4 ) K. Ogawa, T. Shoji, H. Aoki, N. Fujita and T. Torigoe, JSME International Journal A, 44, 507 (2001).

5 ) A. H. Bartlett and R. D. Maschio, J. American Ceram. Soc., 78, 1018 (1995).

6 ) G. M. Newaz and S. Q. Nusier, J. Engineering Materials and Technology, 120, 149 (1998).

7 ) M. F. Kanninen, Int. Journ. of Fracture, 9, 83 (1973).

$8)$ R. A. Miller, J. American Ceram. Soc., 67, 517 (1984).

9) A. Rabiei and A. G. Evans, Acta mater., 48, 3963 (2000).

10）中山真人, 和田克夫，橋本英雄，下村慶一，日本機械学 会 第 5 回機械材料・材料加工技術講演会講演論文集, 5 , 159 (1977)

11）高琳, 加藤昌彦, 中佐啓治郎, 番匠映仁, 西田秀高, 材料, 51, 101 (2002).

12) D. Zhang, M. Kato and K. Nakasa, J Soc. Mat. Sci., Japan, 48, 636 (1999). 